\title{
Gross composition of raw camel's milk produced in Turkey
}

\author{
Ayse Demet KARAMAN ${ }^{1,2 *}$ (D), Filiz YILDIZ AKGÜL ${ }^{1}$ (D), Serdal ÖĞÜT² (D), Hale SEÇİLMİs CANBAY ${ }^{4}$ (D), \\ Valente ALVAREZ ${ }^{2}$
}

\begin{abstract}
The composition and quality of goat milk is determined, but there is no similar studies on Turkish camel's milk. Raw camel's milk was collected from one-humped camels at a farm in western Turkey and evaluated for its physicochemical components and microbial properties. The dispersion of chemical composition values were found to be at similar levels in this study. However, they were lower than small amounts of monosaccharides such as fructose and glucose. Also, the camel's milk was found to be a good source of zinc and vitamin C. The levels of yeast, mold, and coliform bacteria in the camel's milk samples were low. Gas liquid chromatography analysis of milk fat showed that the predominant fatty acids were C16:0, C18:1, C14:0, C16:1 and C18:0. Saturated fatty acids average content was $59.33 \%$ and unsaturated fatty acids content was $40.74 \%$ of total fatty acids with low (2.12) atherogenic index (AI). The ratio of unsaturated/saturated acid (0.69\%) was more favorable in these samples of Turkish camel's milk compared with that of cow's or goat's milk as well as some other camel's milk studies. The study's results suggest that environmental and geographic conditions where camels are raised may cause variation in the composition of raw camel's milk.
\end{abstract}

Keywords: camel's milk; chemical composition; fatty acids; microbial quality; Turkey.

Practical Application: Physicochemical and microbial properties of Turkish raw camel milk.

\section{Introduction}

For centuries, the camel was not only an economic means of transport for communities living in arid regions, but was also valued as a good source of milk. Camels are able to live in hot and harsh conditions and withstand hunger and thirst (Yagil, 1982; Çalışkan, 2016; Önkal \& Bozkurt, 2019). According to a Food and Agriculture Organization report (FAO), there are around 27.7 million camels around the globe, most in Mali, Somalia, Nigeria, Ethiopia and Saudi Arabia (Food and Agriculture Organization, 2014).

The camel population has increased in the world as well as in Turkey between 2012-2017 (Turkish Statistical Institute, 2017). According to Figure 1, if the rising trend in the world, in Turkey, as well as in Aydin continues, the estimated camel numbers will be 2264 in Turkey in 2025. In Turkey, camels are used for sport and meat. Camels are often raised for camel wrestling. Camel meat is also used in sausage production in Turkey. Interest in raising camels for wrestling and sausage production continues to increase and İncirliova (Aydın) is the only district where camel sausage is produced in Turkey (Çalışkan, 2016). However, the number of female camels remains small because females are raised only for impregnation by male camels and to nurse male camel cubs for wrestling (Çalışkan, 2016). According to the data of Turkish Statistical Institute (2017), there are 1,708 camels in Turkey; 1,105 camels in the Aegean region; and 584 camels in Aydin province (Figure 1). It should be remarked that Turkey has a variety of climates and the western region where Aydın city is located is suitable for camel breeding due to its hot summers and warm winters (Turkey, 2020). In recent years, many researchers have identified the health benefits of camel's milk, and now camels are also raised for milking. In Turkey, camel farms have the opportunity to produce camel's milk, besides raising camels for wrestling, particularly for therapeutic purposes (Koc \& Atasever, 2016).

In addition to camel's milk being nutritious, it has properties that are suggested to be angiotension I-converting enzymeinhibition, antitoxic, antiviral, antirheumatoid arthritis, wound healing, antiinflammation, antihypertensive, antidiabetic, anticancer, hypocholesterolemic, hypoglycemic, antimicrobial and hypoallergenicity and its properties make it potentially useful in treating illnesses (Konuspayeva et al., 2008; Al Haj \& Al Kanhal, 2010; Ibrahim et al., 2018). Because of camel's milk aforementioned potentially beneficial properties, it has been used to augment drug treatments for metabolic and autoimmune diseases, hepatitis, Rota viral diarrhea, tuberculosis, cancer, diabetes, liver cirrhosis, rickets, autism, and Crohn's disease, which are assessed in some clinical trials, case reports, and in vivo/in vitro studies (Zibaee et al., 2015). Human and animal experiments have found camel's milk is effective in controlling diabetes. One study showed the prevalence of diabetes among camel breeders in India who consume large amounts of camel's milk is zero \% compared to 5.5\% in other populations (Agrawal et al., 2011). The efficiency of camel's milk in treating food allergies is confirmed

${ }^{1}$ Department of Dairy Technology, Faculty of Agriculture, Aydin Adnan Menderes University, Aydin, Turkey

${ }^{2}$ Department of Food Science and Technology, CFAES, The Ohio State University, Columbus, OHIO, United States of America

${ }^{3}$ Department of Nutrition and Dietetics, Faculty of Health Science, Aydin Adnan Menderes University, Aydin, Turkey

${ }^{4}$ Department of Bioengineering, Faculty of Engineering and Architecture, Burdur Mehmet Akif Ersoy University, Burdur, Turkey

*Corresponding author: demet.karaman@adu.edu.tr 


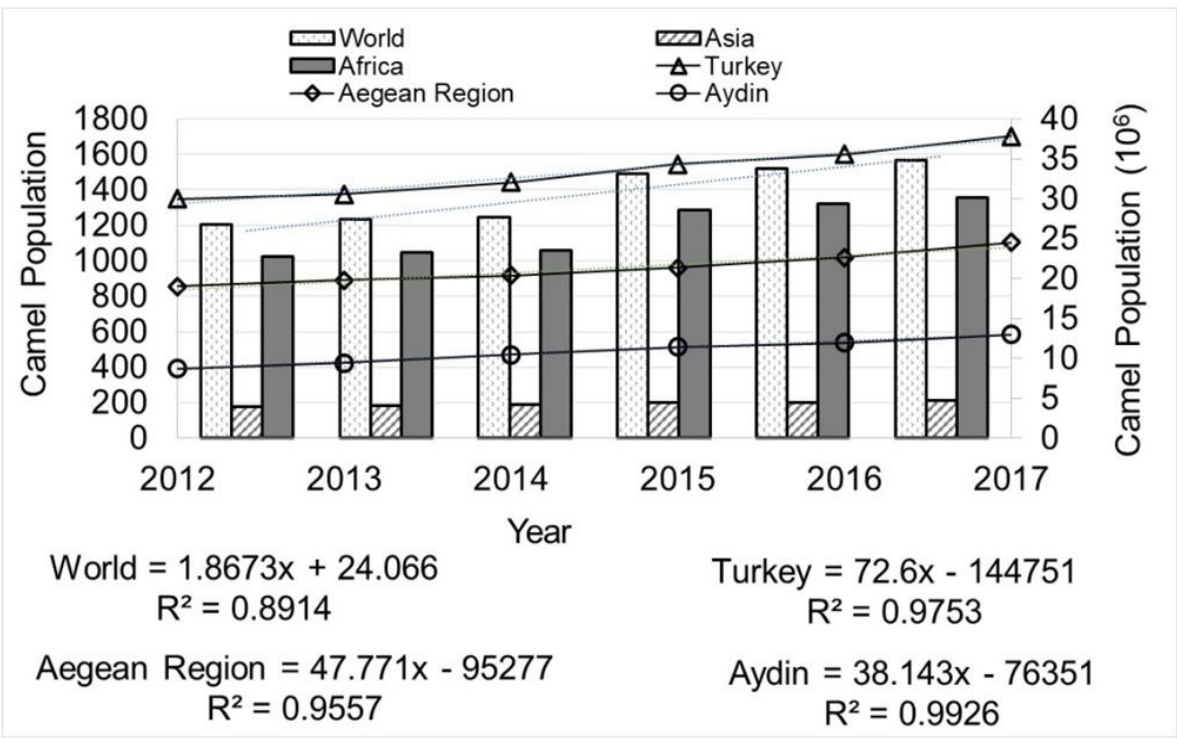

Figure 1. Camel numbers by years (head animal).

by the authors. Consumption of camel's milk by a four-year-old girl for 40 days, a fifteen-year-old child for 30 days, and some twenty-one-year-old adults for two weeks resulted in a positive impact on autism symptoms (Shabo et al., 2005; Yagil, 2013). Children with autism who consumed camel milk experienced reduced autism symptoms and improved motor skills, language, cognition etc (Panwar et al., 2015). Additionally, some suffering from immune system disorders such as multiple sclerosis and Crohn's disease self-report that drinking camel's milk improves their symptoms. However, there are currently no studies that suggest camel's milk is effective as a treatment for autoimmune diseases (Hammam, 2019). An animal study in 2010 indicated that fermented camel's milk had a higher content of sodium and potassium and stopped diarrhea in model rats (Mona, 2010). Studies of diabetic experimental animals have found that drinking camel's milk prevented kidney damage associated with diabetes (Shori, 2015; Kaskous, 2016). Another investigation revealed that the cellular immune response of chronic hepatitis $B$ patients was enhanced by drinking Bactrian camel's milk for one year (Saltanat et al., 2009).

In the last fifty years, milk consumption has increased by $17 \%$ in all every countries for all mammals except for cows (Khalesi et al., 2017). Camel's milk provides the necessary nutrients for human nutrition, and it can be used as an alternative to cow's milk (Al haj and Al Kanhal, 2010). Beside its health benefits, camel's milk has various potential superior nutritional components when compared to other mammals' milk. Camel's milk has 30 times more vitamin $\mathrm{C}$ as compared to cow's milk, and six times more than in human milk (Gizachew et al., 2014). Compared with ruminants' milk, camel's milk contains less sugar and cholesterol, and higher amounts of potassium, sodium, copper, iron, magnesium, and zinc. Additionally, it is lower in protein, but higher in vitamins, and contains higher concentrations of insulin than ruminants' milk (Yadav et al., 2015). Regarding proteins, while total caseins and $\kappa$-casein in camel's milk are lower, $\beta$ - casein is higher than in cow's milk. Camel's milk is rich in whey proteins such as immunoglobulins, lactoferrin, lysozyme, $\alpha$-lactalbumin, and serum albumin, but lacks $\beta$-lactoglobulin when compared to whey proteins in cow's milk (Maqsood et al., 2019).

The literature shows that there are specific whey proteins that are exclusively found in camel's milk: whey acidic protein (WAP), peptidoglycan-protein (PGRP), immunoglobulins (IgGs) and camel whey basic protein (CWBP) (El Hatmi et al., 2015). The antibacterial agents such as lysozyme, lactoferrin and immunoglobulin are present in bovine and buffaloes' milk. Therefore, camel's milk and its products' properties make it promising and attractive for future industry investment (Mohamed et al., 2014). Most recent studies that have focused on the compositional properties and functions of camel's milk and microbiological quality analyzed milk from camels in Arabia (El-Hatmi et al., 2015; Konuspayeva et al., 2014; Sesh et al., 2012; Akbar, 2015; Yadav et al., 2015; Maqsood et al., 2019; Nagy et al., 2019) and a few are in other countries (Omar et al., 2010; Zhao et al., 2015). In Turkey, however, to the best of our knowledge, no work has been conducted on camel milk's gross composition, minerals and sugars. More data is needed to encourage the potential of camels as a dairy animal as well as processing alternative camel's milk dairy products. Therefore, this study aimed to evaluate the physicochemical properties and microbial flora of raw camel's milk produced in Aydin, Turkey.

\section{Materials and methods}

\subsection{Collection of camel's milk samples}

Raw camel's milk samples were collected from camel herds that are raised for manual milking in various locations around Incirliova, Aydin. The samples were collected at 6:00 am (September and October) from one-humped native camels and Afghan camels, aseptically taken in sterile glass bottles (totally $350 \mathrm{~mL}$ ), and kept on ice $\left(+4^{\circ} \mathrm{C}\right)$. Animals generally breed and grazed on a land mainly characterised by clover herb (Medicago sativa), barley flakes (Hordeum vulgare), vetch (Lathyrus, Common vecth), thistle (Ononis spinosa), milk thistle 
(Tribulus terrestris), straw, fodder and other endemic plants. Twenty samples of fresh camel milk were collected from two to four-year-old animals in Aydın, which has warm and hot seasons throughout the year. The samples were transported to the Scientific and Technology Application and Research Center (BILTEKMER, Mehmet Akif Ersoy University) for vitamin and sugar analyses, and to the Agricultural Biotechnology and Food Safety Center (TARBIYOMER Aydın Adnan Menderes University) for physicochemical and microbial analyses. The samples were stored at refrigeration temperature $\left(+4{ }^{\circ} \mathrm{C}\right)$ until analysis. All analyses were completed as soon as the samples reached the laboratories.

\subsection{Physicochemical analyses of camel's milk samples}

The raw camel's milk was analyzed for total solids, ash and fat percent by gravimetric and Gerber methods, respectively (Ankara, 1978, 1994). Total nitrogen and protein contents were measured according to the standard Kjeldahl method using the general conversion factor for dairy products of 6.38 (Association of Official Analytical Chemists, 1990). Milk pH was measured using a pHmeter (Adwa, Romania) with a combined glass electrode. Density was measured at $15^{\circ} \mathrm{C}$ with a lactodansimeter. All analyses were done in triplicate and results were expressed as mean values \pm standard deviation. Lactose, glucose and fructose were analyzed by HPLC (Shimadzu prominence) according to the Turkish Standard method (Turkish Standards Institution, 2008). HPLC was equipped with a 10A RID detector (Shimadzu, 20ACBM), colon oven (Shimadzu, CTO-10ASVp), pump (Shimadzu, LC 20 AT) and auto sampler (Shimadzu, SIL 20ACHT). The LC Solution computer software program was used. An isocratic HPLC method involves the amobile phase of acetonitrile: water $\mathrm{H} 20$ (20: 80, v/v) ratio, ODS 4 column $\left(250 \mathrm{~mm}^{\star} 4,6,5 \mu\right)$ at a flow of $1 \mathrm{~mL} / \mathrm{min}$. Lactose, glucose and fructose were identified by retention time and were quantified by peak area. Two grams of camel's milk was added to $2 \mathrm{~mL}$ of ethanol, dissolved and filtered, and then the sample was injected into the chromatographer.

\subsection{Fatty acid, mineral and vitamin analyses}

Proportional FA compositions of the camel's milk samples were performed in their FA methyl esters (FAME) according to Ackman (1998) and Bannon et al. (1982). Concentrations of vitamins $\mathrm{C}$ and $\mathrm{E}$ were measured by Shimadzu Prominence HPLC. The water-soluble vitamin (vitamin C) was extracted using the procedure reported by Tomovska et al. (2018). The fat-soluble vitamin (vitamin E, tocopherol) was analyzed chromatographically as published by Lampi et al. (1999). Elemental analysis ( $\mathrm{Zn}, \mathrm{Cu}$, $\mathrm{Fe}, \mathrm{Mn}$ ) was performed by Perkin Elmer Optima 8000 ICP-OES. Samples were prepared according to the Nóbrega et al. (2012) method. The microwave oven condition lines were 15 minutes and $110^{\circ} \mathrm{C}$ for both step 1 and step 2 .

\subsection{Microbiological analysis}

The total bacterial count (TBC), lactic acid bacterial count, coliform count, and yeast and molds counts were determined for the camel's milk. Preparation of serial dilution, culturing method, and incubation are analyzed as given in Table 1 . Counting of the developed colonies (cfu/mL) was done according to standard cultural counting methods (Harrigan \& McCance, 1976; Halkman \& Ayhan, 2000).

\subsection{Statistical analysis}

Variance analysis was carried out using SPSS (Version 18 Statistics for Windows, United States).

\section{Results and discussions}

Changes in gross composition (protein, lactose, fat, ash, and total solid, etc.) of the raw camel's milk are given in Table 2.

The $\mathrm{pH}$ and titratable acidity values in this study were found in the range of 6.22 to 6.56 and 0.13 to $0.25 \% \mathrm{w} / \mathrm{v}$, respectively. The $\mathrm{pH}$ values were relatively lower, while titratable acidity (Fouzia et al., 2013) was higher, related to microbial flora producing lactic acid during the milking conditions at ambient temperature as reported by Ismaili et al. (2019) or related to vitamin $\mathrm{C}$ contents.

The percentage of fat, protein, ash, dry matter contents, and the density of the camel's milk samples are shown in Table 2, and the mean values and standard deviation were as follows: fat $3.28 \pm 0.48$, protein $3.10 \pm 0.10$, ash $0.83 \pm 0.04$, dry matter $11.83 \pm 0.41$ and density $1.03 \pm 0.0$, respectively. A

Table 1. Media used in the analysis of microorganisms and incubation conditions.

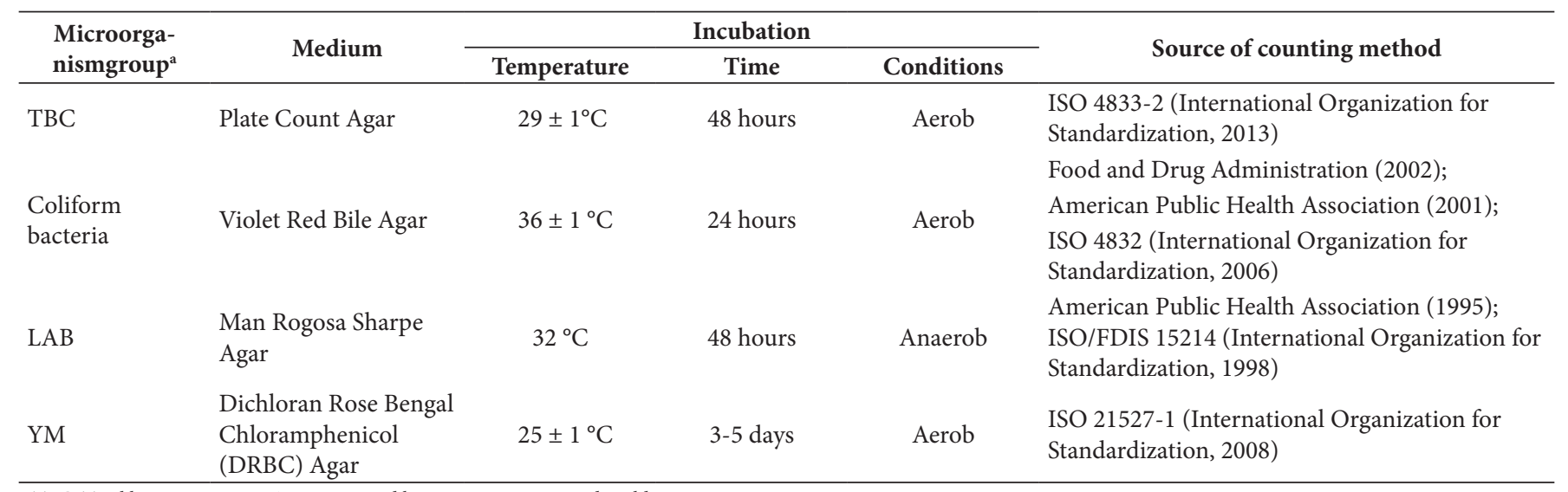

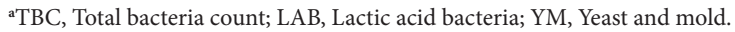


Table 2. Physicochemical properties of raw camel's milk samples.

\begin{tabular}{lccc}
\hline \multicolumn{1}{c}{ Properties } & Min. value & Max. value & Average $\pm \mathbf{S D}^{\mathbf{a}}$ \\
\hline $\mathrm{pH}$ & 6.22 & 6.56 & $6.37 \pm 0.05$ \\
Titratable acidity \% w/v & 0.13 & 0.25 & $0.19 \pm 0.02$ \\
Density g/mL & 1.02 & 1.03 & $1.03 \pm 0.0$ \\
Fat, \% & 2.30 & 5.10 & $3.28 \pm 0.48$ \\
Fat in dry matter, \% & 19.39 & 37.61 & $27.43 \pm 3.29$ \\
Protein, \% & 2.70 & 3.40 & $3.10 \pm 0.10$ \\
Protein in dry matter, \% & 22.86 & 29.72 & $26.33 \pm 1.12$ \\
Ash, \% & 0.72 & 1.01 & $0.83 \pm 0.04$ \\
Ash in dry matter, \% & 6.43 & 7.44 & $7.02 \pm 0.20$ \\
Dry matter, \% & 11.09 & 13.56 & $11.83 \pm 0.41$ \\
Lactose, mg/100 g & 4.08 & 6.09 & $5.32 \pm 0.39$ \\
Fructose, mg/100 g & 0.14 & 0.57 & $0.30 \pm 0.08$ \\
Glucose, mg/100 g & 0.03 & 0.46 & $0.19 \pm 0.07$ \\
\hline
\end{tabular}

aSD, Standard deviation

similar range of density (1.0220 and 1.0310) was reported by Fouzia et al. (2013) and approaches the mean value of $1.03 \%$ reported by Zhao et al. (2015). Although density strongly depends on the dry matter content and the seasonal frequency of watering (Siboukeur, 2005), the composition of camel's milk could vary day to day, depending on geographical locations, feeding conditions, lactation duration, age and health, body weight and kidding, environmental conditions, the intervals between milking, dry periods, livestock management, etc. (Al Haj \& Al Kanhal, 2010). The minimum and maximum levels of chemical components of the milk samples in this study were similar to one-humped camel's milk composition in other studies (Shamsia, 2009; Sesh et al., 2012; Ismaili et al., 2019; Nagy et al., 2019). However, other studies reported higher values for doublehumped Indian and Chinese Bactrian camel's milk in terms of fat, protein, and dry matter contents (Mal \& Pathak, 2010; Zhao et al., 2015). Another study reported that one-humped camel's milk composition was similar to cow's milk in terms of protein, fat and casein contents, but lower than double-humped camel's milk (Semen \& Altıntaş, 2015).

The lactose content of the camel's milk samples ranged from 4.08 to $6.09 \%$ with an average percentage of $5.32 \%$ (Table 2). Other researchers from desert countries reported a mean value of $4.37 \%$ for lactose (Ismaili et al., 2019), 4.15\% (Nagy et al., 2019) and $3.67 \%$ (Sesh et al., 2012) that are lower than the results of this study. This might be related to the fact that camels usually prefer a dehydrated diet and graze on halophytic plants. With this diet, the lactose level in camel's milk decreases (Fouzia et al., 2013). Lactose was found to be the dominant saccharide in the camel's milk samples, along with small amounts of milk monosaccharides such as glucose and fructose, as shown in Table 2. There are limited data published on the monosaccharide composition of camel's milk. Milk lactose study determined values of $4.8 \%$, low enough that it would not affect those who are lactose intolerant (Yadav et al., 2015). Monosaccharides glucose and galactose were detected in cow's milk previously with values of $10 \mathrm{mg} / 100 \mathrm{~mL}$ of milk respectively. The monosaccharide ratio in colostrum is significantly higher than in cow's milk, with about $900 \mathrm{mg} / 100 \mathrm{~mL}$ (Demirci, 1984). One study reported higher amounts of fructose and a considerable variation in components, i.e. fat, protein, water, ash, and lactose in camel's milk as compared with other species' milk (Aqib et al., 2019). Fructose was present in the samples of this study mainly because camels in Aydin stay in fields most of the time in a suitable, warm environment throughout the year, and camel eats grass, bushes and thorns. Little recent research and information can be found on glucose and fructose in camel's milk (Fukuda et al., 2010; Albrecht et al., 2014).

The average concentrations of fatty acid in camel's milk collected from various locations in the Aydin district are shown in Table 3. The main milk fatty acids identified were palmitic acid (C16:0), oleic acid (C18:1 n-9), myristic acid (C14:0), palmitoleic acid (C16:1 n-7), and stearic acid (C18:0) that all account for $89.38 \%$ of the total milk fatty acids. The fatty acid detected at the lowest concentration $(0.31 \%)$ was $\gamma$-Linolenic (GLA, C18:3n6), and short-chain fatty acids (C4-C10) and linoleic (LA, $\omega-6, \mathrm{C} 18: 2 \mathrm{n} 6 \mathrm{c}$ ) were below the detection limit. The fatty acid composition of Turkish camel's milk fat is comparable with previous studies that reported butyric acid 2.1, caproic acid 0.9, caprylic acid 0.6, and linoloic acid 3.8 (\%) (Akbar, 2015). The sum of short chain fatty acids $\mathrm{C} 4$ to $\mathrm{C} 8$ was determined to be $0.52 \%$ in camel's milk samples by Konuspayeva et al. (2014). Short chain fatty acids (C 4:0-C 6:0) ranged between 0.49-3.91\% (average of $2.43 \%$ ) of total fatty acids in milk fat collected from $\mathrm{Al}$ Umari and Al Qatrana (Ereifej et al., 2016). The difference could be related to various factors, such as breed, stage of lactation, diet, seasonality, etc. Saturated fatty acid content in camel's milk fat ranged from 56.22 to $61.98 \%$ (average of 59.33\%) in this study, whereas the unsaturated fatty acids content ranged from 38.20 to $43.77 \%$ (average of $40.74 \%$ ) as shown in Table 3. These results are similar to those of one-humped dromedary camel's milk (Zhang et al., 2005; Ereifej et al., 2016). This dietary characteristic is an important finding because intake of unsaturated fatty acids has been reported to decrease the risk of diseases like hypercholesterolemic and coronary heart disease (Roche, 1999). The predominant saturated fatty acids in camel's milk, in our study in Turkey were C16:0, C18:0, and C14:0 (Table 3), which were similar to those of dromedary and Bactrian camels reported by Zhao et al. (2015) in different countries. The proportion of polyunsaturated fatty acids (PUFA) was $2.68 \%$, of monounsaturated (MUFA) $38.06 \%$, and of unsaturated (UNSFA) $40.74 \%$ with a ratio of SAT/unsaturated fatty acid of 1.46 . The fatty acid composition of camel's milk fat found in this study is consistent with an earlier report by Alichanidis et al. (2016). Suitable amounts of essential fatty acids were found in camel's milk fat. In the modern Western diet, excessive quantities of omega-6 PUFA and elevated omega-6/omega-3 ratios enhance cardiovascular illness, cancer, and inflammatory and autoimmune illnesses, while a reduced omega-6/omega-3 ratio has suppressive impacts (Simopoulos, 2008).

The atherogenic index (AI), which is related to atherogenic acids (C12:0, C14:0, and C16:0), was 2.12 (Table 3). The low AI (C12:0, C14:0, and C16:0) level was similar to earlier findings (Konuspayeva et al., 2008). Lower AI can decrease the total and LDL-cholesterol in human blood plasma. However, significantly lower AI differences among breeds have been reported by the same authors (Yurchenko et al., 2018). An important indicator of the dietary quality of milk is the ratio of unsaturated fatty acids/saturated fatty acids. The ratios reported are 0.45 for 
Bactrian and 0.43 for dromedary milk. Other mammals' ratios are 0.30 for cows' milk and 0.32 for goats' milk (Cardak et al., 2003; Konuspayeva et al., 2008). These values were lower than the ratio of unsaturated fatty acids/saturated fatty acids found in this study, where the average was $0.69 \%$ (Table 3). Higher levels of medium-chain fatty acids are generally regarded as useful to human health because they are easier to absorb and metabolize than long-chain fatty acids (Konuspayeva et al.,

Table 3. Fatty acids content of raw camel's milk (\%).

\begin{tabular}{|c|c|c|c|}
\hline Fatty acids & Min. value & Max. value & Averages \pm SD \\
\hline Butryic C4:0 & - & - & - \\
\hline Caproic C6:0 & - & - & - \\
\hline Caprylic C8:0 & - & - & - \\
\hline Capric C10:0 & 0.29 & 1.32 & $0.71 \pm 0.20$ \\
\hline Undecanoic C11:0 & - & - & - \\
\hline Lauric C12:0 & 1.06 & 1.53 & $1.24 \pm 0.07$ \\
\hline Tridecanoic C13:0 & - & - & - \\
\hline Myristic C14:0 & 11.47 & 14.42 & $13.34 \pm 0.44$ \\
\hline Myristoleic C14:1 & 1.16 & 2.40 & $1.86 \pm 0.19$ \\
\hline Pentadecanoic C15:0 & 1.09 & 1.56 & $1.24 \pm 0.07$ \\
\hline $\begin{array}{l}\text { cis-10-Pentadecenoic } \\
\text { C15:1 }\end{array}$ & 0.57 & 0.92 & $0.79 \pm 0.05$ \\
\hline Palmitic C16:0 & 30.09 & 34.16 & $31.70 \pm 0.62$ \\
\hline Palmitoleic C16:1 & 8.16 & 13.72 & $10.74 \pm 1.09$ \\
\hline Heptadecanoic C17:0 & 0.47 & 1.32 & $0.80 \pm 0.13$ \\
\hline $\begin{array}{l}\text { cis-10-Heptadecenoic } \\
\text { C17:1 }\end{array}$ & 0.41 & 0.65 & $0.55 \pm 0.04$ \\
\hline Stearic C18:0 & 8.35 & 11.92 & $10.30 \pm 0.67$ \\
\hline Oleic C18:1n9c $(n-9)$ & 21.20 & 24.66 & $23.30 \pm 0.53$ \\
\hline Elaidic C18:1n9t $(n-9)$ & 0.47 & 0.95 & $0.83 \pm 0.08$ \\
\hline $\begin{array}{l}\text { Linoleic (LA, } \omega-6) \\
\text { C18:2n6c }(n-6)\end{array}$ & - & - & - \\
\hline $\begin{array}{l}\text { Linolelaidic }(\omega-6) \\
\text { C18:2n6t }(n-6)\end{array}$ & 1.39 & 2,03 & $1.80 \pm 0.10$ \\
\hline $\begin{array}{l}\gamma \text {-Linolenic (GLA, } \omega-6) \\
\text { C18:3n6 }(n-6)\end{array}$ & 0.21 & 0.38 & $0.31 \pm 0.03$ \\
\hline $\begin{array}{l}\text { a-Linolenic (ALA, } \omega-3) \\
\text { C18:3n3 }(n-3)\end{array}$ & 0.23 & 0.87 & $0.56 \pm 0.12$ \\
\hline $\begin{array}{l}\text { SFA: saturated fatty } \\
\text { acids }\end{array}$ & 56.22 & 61.98 & $59.33 \pm 0.05$ \\
\hline $\begin{array}{l}\text { UNSFA: unsaturated } \\
\text { fatty acids }\end{array}$ & 38.20 & 43.77 & $40.74 \pm 0.89$ \\
\hline $\begin{array}{l}\text { MUFA: monounsaturat } \\
\text { fatty acids }\end{array}$ & 35.87 & 40.72 & $38.06 \pm 0,77$ \\
\hline $\begin{array}{l}\text { PUFA: polyunsaturated } \\
\text { fatty acids }\end{array}$ & 2.33 & 3.05 & $2.68 \pm 0.14$ \\
\hline SFA/UNSFA & 1.28 & 1.62 & $1.46 \pm 0.05$ \\
\hline $\mathrm{n} 6 / \mathrm{n} 3$ & 2.03 & 9.13 & $5.06 \pm 1.26$ \\
\hline Atherogenicity index & 1.94 & 2.38 & $2.12 \pm 0.07$ \\
\hline Total $\omega-3$ & 0.23 & 0.87 & $0.56 \pm 0.12$ \\
\hline Total $\omega-6$ & 1.77 & 2.33 & $2.11 \pm 0.09$ \\
\hline Total $\omega-9$ & 22.15 & 25.57 & $24.13 \pm 0.53$ \\
\hline Desaturation index-14 & 0.09 & 0.15 & $0.12 \pm 0.01$ \\
\hline Desaturation index-16 & 0.20 & 0.31 & $0.25 \pm 0.02$ \\
\hline Desaturation index-18 & 0.05 & 0.68 & $0.31 \pm 0.13$ \\
\hline$C 18: \ln 9 c+9 t(n-9)$ & 22.15 & 25.57 & $24.13 \pm 0.53$ \\
\hline
\end{tabular}

2008). The fat in camel's milk is lower than in cow's milk, and it is a smaller globule that can be easily absorbed and digested. The lower fat content of camel's milk is a benefit for people with heart disease because a build-up of fat in the arteries can lead to strokes (Hammam, 2019). Camel's milk seems to be very different from other mammalian milks consumed by humans in terms of unsaturated fatty acid composition and in its low content of short-chain fatty acids and higher unsaturated fatty acids (Konuspayeva et al., 2008). Given these significant differences, camel's milk may be a healthier option for milk consumers.

The concentrations of essential trace elements (zinc, copper, iron, manganese) are given in Table 4 . There was a high concentration of $\mathrm{Zn}$, but $\mathrm{Mn}, \mathrm{Fe}, \mathrm{Cu}$ were not found. Thus, camel's milk is a good source of zinc, which could be associated with animals that graze during the summer and spring months. It has been reported that during the hot summer and warm spring seasons in Aydin, zinc concentrations in camel's milk are high. Milk Zn concentration could be the discriminant parameter among camel's milk from different locations in Turkey. The concentration of $\mathrm{Zn}$ and other essential minerals is influenced by plant variety and overall environment (Osorio et al., 2015). These results are in agreement with previous reports Haddadin et al. (2008) and AL-Ayadhi \& Halepoto (2017) but differ from findings by others Shamsia (2009); Mal \& Pathak (2010); Alichanidis et al. (2016).

Camel's milk is known as a good source of vitamin C (34.16 mg/L), with 3-5 times more vitamin $\mathrm{C}$ than bovine milk, whereas the Vitamin E concentration in camel's milk is similar to that of bovine milk ( $\mathrm{Al} \mathrm{Haj} \mathrm{\&} \mathrm{Al} \mathrm{Kanhal,} \mathrm{2010;}$ Brezovečki et al., 2015). The above mean value of vitamin C content is similar to the concentration of this vitamin found by other authors Haddadin et al. (2008) $(33.0 \pm 1.07 \mathrm{mg} / \mathrm{L}$ mean value), Zhao et al. (2015) (27.6-34.3 $\mathrm{mg} / \mathrm{L})$ for one-humped camels, and Konuspayeva et al. (2014) $(26.1 \pm 3.5 \mathrm{mg} / \mathrm{L})$ in Saudi Arabia. The mean value of vitamin E $(2.49 \pm 0.87)$ in the milk samples was lower than the content reported by Haddadin et al. (2008) (17.8 $\pm 5.8 \mathrm{mg} / \mathrm{L}$ mean value), but higher than Zhao et al. (2015) (1.45-1.55 mg/L) and Konuspayeva et al. (2014) $(20.2 \mathrm{mg} / 100 \mathrm{~mL})$. Thus, the camel's milk samples in this study are nutritionally useful, especially as an excellent source of vitamins $\mathrm{C}$ and $\mathrm{E}$. The low $\mathrm{pH}$ and high acidity of camel's milk (Table 2) is most likely due to the high vitamin $\mathrm{C}$ content (Table 4), which is also a factor that increases its shelf life (El Hatmi et al., 2015; AL-Ayadhi \& Halepoto, 2017).

Microbiological results are shown in Table 5. There are no microbiological norms for camel's milk in Turkey. Thus, the microbiological quality of samples in this study was assessed

Table 4. Mineral matter and vitamin contents of raw camel's milk. ${ }^{a}$

\begin{tabular}{lccc}
\hline \multicolumn{1}{c}{ Content } & Min. value & Max. value & Averages \pm SD \\
\hline $\mathrm{Zn}, \mu \mathrm{g} / \mathrm{g}$ & 5.65 & 9.32 & $7.34 \pm 0.65$ \\
$\mathrm{Mn}, \mu \mathrm{g} / \mathrm{g}$ & nd & nd & nd \\
$\mathrm{Fe}, \mu \mathrm{g} / \mathrm{g}$ & nd & nd & nd \\
$\mathrm{Cu}, \mu \mathrm{g} / \mathrm{g}$ & nd & nd & nd \\
Vitamin E, mg/L & 1.79 & 3.19 & $2.49 \pm 0.87$ \\
Vitamin C, mg/L & 9.56 & 75.24 & $27.57 \pm 12.66$ \\
\hline
\end{tabular}


Table 5. Microbiological properties of raw camel's milk ( $\log \mathrm{cfu} / \mathrm{mL})$.

\begin{tabular}{lccc}
\hline \multicolumn{1}{c}{ Microorganism } & Min. value & Max. value & Averages \pm SD \\
\hline TAMB & 2.72 & 4.23 & $3.71 \pm 3.43$ \\
Coliform bacteria & 2.04 & 3.65 & $3.11 \pm 2.87$ \\
Molds and Yeasts & 3.15 & 5.17 & $4.67 \pm 4.41$ \\
Lactic acid bacteria & 4.49 & 5.98 & $5.63 \pm 5.23$ \\
\hline
\end{tabular}

using procedures for milk from cows, sheep, goats and buffaloes. The TAMB content of camel's milk (Table 5) varied between 2.72 and 4.23 with an average of $3.71 \pm 3.43 \log \mathrm{cfu} / \mathrm{mL}$. The total bacteria count of the raw camel's milk samples was lower than that reported by Benkerroum et al. (2003); Abera et al. (2016); Mohamed et al. (2014); Ismaili et al. (2019), and also Turkish law (Turkey, 2000, 2017). The TAMB count, which reflects sanitary conditions (Abera et al., 2016), was low in this study, suggesting the camel's milk samples are safe for human consumption. Moreover, the low presence of coliform bacteria $(3.11 \pm 2.87$ mean value) in these samples implies that there is no risk of any fecal contamination. This indicates the application of good sanitary practices during milking and handling (milking routine, cleaning and sanitation, etc.) of the product. The low total count of coliform bacteria could also be related to high contents of vitamin $\mathrm{C}$ and high $\mathrm{pH}$ acidity (Table 2 and Table 4), which inhibit the growth of harmful bacteria and contribute to the longterm preservation of camel's milk as mentioned previously (El Hatmi et al., 2015). Also, camel's milk may contain a number of protective proteins (e.g., lactoferrin, lysozyme, immunoglobulin) (AL-Ayadhi \& Halepoto, 2017; Hammam, 2019). In a recent study (Ismaili et al., 2019), about half of the camel's milk samples analyzed contained high total coliform counts due to a lack of refrigeration in milk storage/transportation and noncompliance with hygienic conditions during milking, which indicates an intense microbial contamination, the opposite of the results of this study. The yeast and mold counts of the camel's milk samples in this study ranged from 3.15 to $5.17 \mathrm{log} \mathrm{cfu} / \mathrm{mL}$ with an average of $4.67 \pm 4.41$ (Table 5). The average value is less than the values found in camel's milk samples in Sudan and Morocco (Mohamed et al., 2014) and (Ismaili et al., 2019), respectively. The lower yeast and mold counts could be because the natural milk $\mathrm{pH}$ favors bacterial growth and lowers yeast and mold content as detected in the samples of this study. Counts of LAB ranged between 4.49 and $5.98 \log \mathrm{cfu} / \mathrm{mL}$ at low levels and the average number was $5.63 \pm 5.23 \mathrm{log} \mathrm{cfu} / \mathrm{mL}$. The count numbers were lower to those reported by Benkerroum et al. (2003) and Ismaili et al. (2019). Additionally, the high levels of lysozyme and ascorbic acid (Table 4 ) in these camel's milk samples may be attributed to the low quantities of $\mathrm{LAB}$ as mentioned previously by other researchers (Belkheir et al., 2016).

\section{Conclusion}

One-humped camel's milk showed slight differences in gross composition when compared to other types of camel's milk. The difference was observed in the most discriminating parameters, including zinc content, vitamin $\mathrm{C}, \mathrm{pH}$, short-chain fatty acids, and linoleic acid. The microbial content related to total counts of yeast, molds and coliform bacteria were below the acceptable limits for camel's milk after milking. These properties make camel's milk a potentially valuable dietary food. These findings are a useful contribution to the limited information available regarding the chemistry and microbiological properties of camel's milk in Turkey. Due to its unique chemical composition and nutritional value, marketing of camel's milk could be extended to manufacturers of processed products, such as ice cream, butter and cheese, as an alternative to liquid milk. However, further studies are needed in this field to support and enhance the production and utilization of this valuable food.

\section{Acknowledgements}

The authors would like to thank Mr. Gürşad KALE (Former Mayor of İncirliova Municipality) and Mr. Aytekin KAYA (Mayor of İncirliova) for providing the camel's milk analyzed in this study.

\section{References}

Abera, T., Legesse, Y., Mummed, B., \& Urga, B. (2016). Bacteriological quality of raw camel milk along the market value chain in Fafen zone, Ethiopian Somali regional state. BMC Research Notes, 9, 285. http://dx.doi.org/10.1186/s13104-016-2088-1. PMid:27230392.

Ackman, R. G. (1998). Remarks on official methods employing boron trifluoride in the preparation of methyl esters of the fatty acids of fish oils. Journal of the American Oil Chemists' Society, 75(4), 541545. http://dx.doi.org/10.1007/s11746-998-0263-9.

Agrawal, R. P., Jain, S., Shah, S., Chopra, A., \& Agarwal, V. (2011). Effect of camel milk on glycemic control and insulin requirement in patients with Type 1 diabetes: 2-years randomized controlled trial. European Journal of Clinical Nutrition, 65(9), 1048-1052. http:// dx.doi.org/10.1038/ejcn.2011.98. PMid:21629270.

Akbar, M. (2015). Camel milk. Retrieved from: https://www.foodjournal. pk/2015/July-August-2015/PDF-July-August-2015/Article-MehmoodAkbar.pdf

Al haj, O. A., \& Al Kanhal, H. A. (2010). Compositional, technological and nutritional aspects of dromedary camel milk. International Dairy Journal, 20(12), 811-821. http://dx.doi.org/10.1016/j.idairyj.2010.04.003.

AL-Ayadhi, L., \& Halepoto, D. M. (2017). Camel milk as a potential nutritional therapy in autism. In R. R. Watson, R. J. Collier \& V. R. Preedy (Eds.), Nutrients in dairy and their implications for health and disease. London: Academic Press. http://dx.doi.org/10.1016/ B978-0-12-809762-5.00030-9.

Albrecht, S., Lane, J. A., Mariño, K., Al Busadah, K. A., Carrington, S. D., Hickey, R. M., \& Rudd, P. M. (2014). A comparative study of free oligosaccharides in the milk of domestic animals. British Journal of Nutrition, 111(7), 1313-1328. http://dx.doi.org/10.1017/ S0007114513003772. PMid:24635885.

Alichanidis, E., Moatsou, G., \& Polychroniadou, A. (2016). Composition and properties of non-cow milk and products. non-bovine milk and milk products. In E. Tsakalidou \& K. Papadimitriou (Eds.), Nonbovine milk and milk products (pp. 81-116). Amsterdam: Elsevier.

American Public Health Association - APHA. (1995). Standarts methods for the examination of dairy products. New York: APHA.

American Public Health Association - APHA. (2001). Compendium of methods for the microbiological examination of foods. Washington: APHA.

Ankara. (1978). TSE 3046: fat level determination in cheese-Peynirde yă̆ miktarı tayini (Van-Gulik Metodu) (Necatibey Cad., No. 112). Bakanlıklar, Ankara. 
Ankara. (1994). TSE 1018: raw milk standart-çiğ süt standarti (Necatibey Cad., No. 112). Bakanlıklar, Ankara.

Aqib, A. I., Fakhar-e-Alam Kulyar, M., Ashfaq, K., Bhutta, Z. A., Shoaib, M., \& Ahmed, R. (2019). Camel milk insuline: pathophysiological and molecular repository. Trends in Food Science \& Technology, 88, 497-504. http://dx.doi.org/10.1016/j.tifs.2019.04.009.

Association of Official Analytical Chemists - AOAC. (1990). Official methods of analysis (12 $2^{\text {th }}$ ed.). Washington: AOAC International.

Bannon, C. D., Craske, J. D., Hai, N. T., Harper, N. L., \& O’Rourke, K. L. (1982). Analysis of fatty acid methyl esters with high accuracy and reliability: II. Methylation of fats and oils with boron trifluoridemethanol. Journal of Chromatography A, 247(1), 63-69. http://dx.doi. org/10.1016/S0021-9673(00)84856-6.

Belkheir, K., Centeno, J. A., Zadi-karam, H., Karam, N. E., \& Carballo, J. (2016). Potential technological interest of indigenous lactic acid bacteria from Algerian camel milk. Italian Journal of Food Science, 28, 598-611.

Benkerroum, N., Boughdadi, A., Bennani, N., \& Hidane, K. (2003). Microbiological quality assessment of Moroccan camel's milk and identification of predominating lactic acid bacteria. World Journal of Microbiology \& Biotechnology, 19(6), 645-648. http://dx.doi. org/10.1023/A:1025114601811.

Brezovečki, A., Čagal, M., Dermit, Z. F., Mikulec, N., Ljoljić, B. D., \& Antunac, N. (2015). Camel milk and milk products. Mljekarstvo, 65(2), 81-90.

Çalışkan, V. (2016). A world cultural heritage: anatolian camel dealing culture and camel wrestles (İncirliova Municipality Cultural Publications, no. 1). Ankara: Pozitif Matbaa.

Cardak, A. D., Yetişmeyen, A., \& Brückner, H. (2003). Quantitative comparison of free fatty acids in camel, goat and cow milk. Milchwissenchaft, 58(3-4), 128-130.

Demirci, M. (1984). Laktozun insan beslenmesindeki önemi. Journal of the Faculty of Agriculture, 15(3-4), 109-116.

El-Hatmi, H., Jrad, Z., Salhi, I., Aguibi, A., Nadri, A., \& Khorchani, T. (2015). Comparison of composition and whey protein fractions of human, camel, donkey, goat and cow milk. Mljekarstvo, 65(3), 159167. http://dx.doi.org/10.15567/mljekarstvo.2015.0302.

Ereifej, K. I., Aludatt, M. H., AlKhalidy, H. A., Alli, I., \& Rababah, T. (2016). Comparison and characterisation of fat and protein composition for camel milk from eight Jordanian locations. Food Chemistry, 127(1), 282-289. http://dx.doi.org/10.1016/j.foodchem.2010.12.112.

Food and Agriculture Organization - FAO. (2014). FAOSTAT. Rome. Retrieved from http://www.fao.org/faostat/en/\#data/QL

Food and Drug Administration - FDA (2002). Food and Drug Administration, Bacteriological Analytical Manual ( $9^{\text {th }}$ Ed). AOAC International: Arlington, USA.

Fouzia, R., Noureddine, S., \& Mebrouk, K. (2013). Evaluation of the factors affecting the variation of the physicochemical composition of Algerian camel's raw milk during different seasons. Advances in Environmental Biology, 7(14), 4879-4884.

Fukuda, K., Yamamoto, A., Ganzorig, K., Khuukhenbaatar, J., Senda, A., Saito, T., \& Urashima, T. (2010). Chemical characterization of the oligosaccharides in Bactrian camel (Camelus bactrianus) milk and colostrum. Journal of Dairy Science, 93(12), 5572-5587. http:// dx.doi.org/10.3168/jds.2010-3151. PMid:21094729.

Gizachew, A., Teha, J., \& Birhanu, T. (2014). Review on medicinal and nutritional values of camel milk. Nature and Science, 12(12), 35-40.

Haddadin, M. S. Y., Gammoh, S. I., \& Robinson, R. K. (2008). Seasonal variations in the chemical composition of camel milk in Jordan. The Journal of Dairy Research, 75(1), 8-12. http://dx.doi.org/10.1017/ S0022029907002750. PMid:17971263.
Halkman, A. K., \& Ayhan, K. (2000). Gidalarin mikrobiyolojik analizi, mikroorganizma sayimi ( $2^{\text {nd }}$ ed.). Ankara: Sim Matbaacilik Ltd.

Hammam, A. R. A. (2019). Compositional and therapeutic properties of camel milk: a review. Emirates Journal of Food and Agriculture, 31(3), 148-152. http://dx.doi.org/10.9755/ejfa.2019.v31.i3.1919.

Harrigan, W. F., \& McCance, M. E. (1976). Laboratory methods in food and dairy microbiology. London: Academic Press .

Ibrahim, H. R., Isono, H., \& Miyata, T. (2018). Potential antioxidant bioactive peptides from camel milk proteins. Animal Nutrition, 4(3), 273-280. http://dx.doi.org/10.1016/j.aninu.2018.05.004. PMid:30175255.

International Organization for Standardization - ISO. (1998). ISO/FDIS 15214: microbiology of food and animal feeding stuffs: horizontal method for the enumeration of mesophilic lactic acid bacteria: colony count technique at $30^{\circ} \mathrm{C}$. Genova: ISO.

International Organization for Standardization - ISO. (2006). ISO 4832: microbiology of food and animal feeding stuffs: horizontal method for the enumeration of coliforms: colony-count technique (pp. 1-6). Genova: ISO.

International Organization for Standardization - ISO. (2008). ISO 21527-1: microbiology of the food and animal feeding stuffs: horizontal method for the detection and enumeration of yeasts and moulds. Part 1: colony-count technique in products with water activity greater than 0.95. Genova: ISO.

International Organization for Standardization - ISO. (2013). ISO 4833-2: microbiology of the food chain: horizontal method for the enumeration of microorganisms. Part 2: colony count at 30 degrees $C$ by the surface plating technique. Genova: ISO.

Ismaili, M. A., Saidi, B., Zahar, M., Hamama, A., \& Ezzaier, R. (2019). Composition and microbial quality of raw camel milk produced in Morocco. Journal of the Saudi Society of Agricultural Sciences, 18(1), 17-21. http://dx.doi.org/10.1016/j.jssas.2016.12.001.

Kaskous, S. (2016). Importance of camel milk for human health. Emirates Journal of Food and Agriculture, 28(3), 158-163. http:// dx.doi.org/10.9755/ejfa.2015-05-296.

Khalesi, M., Salami, M., Moslehishad, M., Winterburn, J., \& MoosaviMovahedi, A. A. (2017). Biomolecular content of camel milk: A traditional superfood towards future healthcare industry. Trends in Food Science \& Technology, 62, 49-58. http://dx.doi.org/10.1016/j. tifs.2017.02.004.

Koc, A., \& Atasever, S. (2016). Production and characteristics of camel milk. In Proceedings of the I International Selçuk-Ephesus Symposium on Culture of Camel-Dealing and Camel Wrestling. Turkey. Retrieved from https://www.researchgate.net/publication/310508382_ Production_and_Characteristics_of_Camel_Milk

Konuspayeva, G., Bernard, F., \& Mussaad, A. (2014). Some lipid components of the camel milk and blood in intensive farm in Saudi Arabia. Emirates Journal of Food and Agriculture, 26(4), 349-353. http://dx.doi.org/10.9755/ejfa.v26i4.17276.

Konuspayeva, G., Lemarie, É., Faye, B., Loiseau, G., \& Montet, D. (2008). Fatty acid and cholesterol composition of camel's (Camelus bactrianus, Camelus dromedarius and hybrids) milk in Kazakhstan. Dairy Science \& Technology, 88(3), 327-340. http://dx.doi.org/10.1051/dst:2008005.

Lampi, A.-M., Kataja, L., Kamal-Eldin, A., \& Vieno, P. (1999). Antioxidant activities of a- and c-tocopherols in the oxidation of rapeseed oil triacylglycerols. Journal of the American Oil Chemists' Society, 76(6), 749-755. http://dx.doi.org/10.1007/s11746-999-0171-7.

Mal, G. \& Pathak, K. M. L. (2010). Camel milk and milk products (pp. 97-103). India: SMVS’ Dairy Year Book. 
Maqsood, S., Al-Dowaila, A., Mudgil, P., Kamal, H., Jobe, B., \& Hassan, H. M. (2019). Comparative characterization of protein and lipid fractions from camel and cow milk, their functionality, antioxidant and antihypertensive properties upon simulated gastro-intestinal digestion. Food Chemistry, 279, 328-338. http://dx.doi.org/10.1016/j. foodchem.2018.12.011. PMid:30611498.

Mohamed, I. M. A., El Zubeir, I., \& El, Y. M. (2014). Effect of heat treatment on keeping quality of camel milk. Annals. Food Science and Technology, 15(2), 239-245.

Mona, E. (2010). Biochemical Effects of Fermented Camel Milk on Diarrhea in Rats. New York Science Journal, 3(5), 106-111.

Nagy, P., Juhász, J., Reiczigel, J., Császár, G., Kocsis, R., \& Varga, L. (2019). Circannual changes in major chemical composition of bulk dromedary camel milk as determined by FT-MIR spectroscopy, and factors of variation. Food Chemistry, 278, 248-253. http://dx.doi. org/10.1016/j.foodchem.2018.11.059. PMid:30583369.

Nóbrega, J. A., Pirola, C., Fialho, L. L., Rota, G., Campos Jordão, C. E. K. M. A., \& Pollo, F. (2012). Microwave-assisted digestion of organic samples: how simple can it become? Talanta, 98, 272-276. http:// dx.doi.org/10.1016/j.talanta.2012.06.079. PMid:22939159.

Omar, A., Harbourne, N., \& Oruna-Concha, M. J. (2010). Quantification of major camel milk proteins by capillary electrophoresis. International Dairy Journal, 58, 31-35. http://dx.doi.org/10.1016/j.idairyj.2016.01.015.

Önkal, A., \& Bozkurt, N. (2019). Deve: Türkiye Diyanet Vakfi İslam Ansiklopedisi. Retrieved from https://islamansiklopedisi.org.tr/deve

Osorio, M. T., Koidis, A., \& Papademas, P. (2015). Major and trace elements in milk and Halloumi cheese as markers for authentication of goat feeding regimes and geographical origin. International Journal of Dairy Technology, 68(4), 573-581. http://dx.doi.org/10.1111/1471-0307.12213.

Panwar, R., Grover, C. R., Kumar, V., Ranga, S., \& Kumar, N. (2015). Camel milk: natural medicine: boon to dairy industry. Dairy Foods. Retrieved from www.dairyfoods.com

Roche, H. M. (1999). Unsaturated fatty acids. The Proceedings of the Nutrition Society, 58(2), 397-401. http://dx.doi.org/10.1017/ S002966519900052X. PMid:10466183.

Saltanat, H., Li, H., Xu, Y., Wang, J., Liu, F., \& Geng, X. H. (2009). The influencesof camel milk on the immune response of chronic hepatitis B patients. Chinese Journal of Cellular and Molecular Immunology, 25(5), 431-436. PMid:19426601.

Semen, Z., \& Altıntaş, A. (2015). Biological and therapeutic effects of dietary camel milk. Türk Veteriner Hekimleri Birliği Dergisi, 3-4, 86-101.

Sesh, P. S. L., Loganathasamy, K., \& Ayyadurai, K. (2012). A study on the chemical composition of ass's and camel's milk. Journal of Dairying, Foods \& Home Sciences, 31(2), 81-84.

Shabo, Y., Barzel, R., Margoulis, M., \& Yagil, R. (2005). Camel milk for food allergies in children. The Israel Medical Association Journal, 7(12), 796. PMid:16382703.

Shamsia, S. M. (2009). Nutritional and therapeutic properties of camel and human milks. International Journal of Genetics and Molecular Biology, (2), 52-58.
Shori, A. B. (2015). Camel milk as a potential therapy for controlling diabetes and its complications: a review of in vivo studies. Journal of Food and Drug Analysis, 23(4), 609-618. PMid:28911476.

Siboukeur, O. (2005). Étude du lait camelin collecté localement: caractéristiques physico-chimiques et microbiologiques; aptitudes à la coagulation (These). Institut National Agronomique El-Harrach-Alger, Alger.

Simopoulos, A. P. (2008). The importance of the omega-6/omega-3 fatty acid ratio in cardiovascular disease and other chronic diseases. Experimental Biology and Medicine, 233(6), 674-688. http://dx.doi. org/10.3181/0711-MR-311. PMid:18408140.

Tomovska, J., Menkovska, M., \& Ayaz Ahmad, M. (2018). Determination of Vitamin C in different types of milk. International Journal of Engineering Science, 7(5), 77-82.

Turkey. (2000, February 14). Raw milk and heat treated milk notification. Official Gazette.

Turkey. (2017, April 27). Turkish kodex: notification on the supply of raw milk. Official Gazette.

Turkey, Turkish Ministry of Forestry and Water Affairs General. (2020). Aydin ilinin iklim durumu. Retrieved from http://izmir.mgm.gov. tr/FILES/iklim/aydin_iklim.pdf

Turkish Standards Institution. (2008). TS 13359: determination of fructose, glucose, saccharose, turanose and maltose of honey by high performance liquid chromatography. Ankara.

Turkish Statistical Institute. (2017). Statistics. Retrieved from http:// www.tuik.gov.tr/PreTablo.do?alt_id=1002

Yadav, A. K., Kumar, R., Priyadarshini, L., \& Singh, J. (2015). Composition and medicinal properties of camel milk: a review. Asian Journal of Dairy and Food Research, 34(2), 83-91. http://dx.doi.org/10.5958/09760563.2015.00018.4

Yagil, R. (1982). Camels and camel milk (FAO Animal production and Health Paper). Rome: FAO.

Yagil, R. R. (2013). Comparative Alternative Medicinal (CAM) properties in camel milk for treatment of epidemic diseases. Journal of Agricultural Science and Technology, 3, 575-580.

Yurchenko, S., Sats, A., Tatar, V., Kaart, T., Mootse, H., \& Jõudu, I. (2018). Fatty acid profile of milk from Saanen and Swedish Landrace goats. Food Chemistry, 254, 326-332. http://dx.doi.org/10.1016/j. foodchem.2018.02.041. PMid:29548460.

Zhang, H., Yao, J., Zhao, D., Liu, H., Li, J., \& Guo, M. (2005). Changes in chemical composition of Alxa Bactrian camel milk during lactation. Journal of Dairy Science, 88(10), 3402-3410. http://dx.doi.org/10.3168/ jds.S0022-0302(05)73024-1. PMid:16162513.

Zhao, D., Bai, Y., \& Niu, Y. (2015). Composition and characteristics of Chinese Bactrian camel milk. Small Ruminant Research, 127, 58-67. http://dx.doi.org/10.1016/j.smallrumres.2015.04.008.

Zibaee, S., Hosseini, S. M., Yousefi, M., Taghipour, A., Kiani, M. A., \& Noras, M. R. (2015). Nutritional and therapeutic characteristics of camel milk in children: a systematic review. Electron Physician, 7(7), 1523-1528. PMid:26767108. 